\title{
消費者が求める畜産物の安心・安全
}

\author{
倉持 泰子 \\ 生活協同組合コープ十勝
}

\section{1. 食肉文化圏としての特徵}

関東から東は豚肉圈，西は牛肉圈とよくいわれ ますが，コープ十勝店舗での利用比率は，豚肉 $54 \%$, 鶏肉 28\%, 牛肉 18\% となっています（2002 年度利用金額対比)。これを重量比に置き換える 之, 単価の低い鶏・豚の比率はさらに高くなりま す。10 年前の共同購入での比率は, 豚肉 $54 \%$, 鶏 肉 $25 \%$, 牛肉 $21 \%$ でしたので, 牛肉の利用は増 えていくだろうという当時の予想は, BSE 問題な ども影響してか，ほぼ横這い状態ではないかと思 います。やはり，北海道は豚肉文化の地域といえ るでしょう。

帯広で生まれ育った私も「肉といえば豚肉」と いう食生活の中で生活してきました。養豚屋さん あ比較的身近にありました。普段の生活で牛肉を 買うことはなかったと思います。当時親は「牛肉 は臭くて硬い」といっていましたので，価格すそ れなりに高かったのであれば，当然なことだと思 います。とはいえ子供の頃（昭和 30 年代）, 肉は 贅沢食材で今ほど豊富に食卓を飾ってはいません でしたが.......。かくしてこの辺りでは，カレーも ステーキもすき焼きむ豚肉で，牛井は見たことも なく，今ではすっかり有名になった「豚井」が家 庭での食卓に載るという，豚肉中心の生活をして きたことになります。

\section{2. 畜肉への消費者の不安}

料理を手伝い始めた頃「豚肉はしっかり中まで 火を通さないといけないよ」とはいわれました が，今日のような肉の安全性へ関心がむけられた のは, 輸入肉のホルモン剤や抗生物質のことで あったと思います。そして一昨年秋の BSE 牛の発 覚, その後の一連の偽装問題など, 業界全体への 不信が広がりました。流通・販売されている食品
は当然安全であるはずという前提が崩れた場合, 商品を選択する拠所を何に求めるのか，あるいは， 何を基準に商品の安心安全を伝えるかが, 改めて 問われる事になりました。日本生協連では，この 事件の 2 年前から, 食の安全を求める運動として 食品衛生法の改正を提起し, 農薬や動物用医薬品 の食品への残留基準作りなど，6 項目の要望を掲 げて取組んでいました。当初むずかしいテーマと 感じましたが，全国で 1373 万筆むの請願署名を 集めることができ，採択への期待が高まりまし た。しかし，2001 年 6 月の国会では審議未了で振 り出しに戻ってしまったため, 次への対策を検討 し始めていたときに, 初めての BSE 問題が報道 されました。この事は予想もしない大変な問題で はありましたが, 結果的にはこれらの一連の問題 が後押しした感じで，今年の 5 月に食品安全基本 法, 改正食品衛生法をはじめとする食品関連法が 成立し，制度面では一歩前進したことになりま す。今後は, 消費者の安心安全が確保される機能 を果たしていくのかを見守りたいと思います。

\section{3. 畜肉へ期待する安心安全の裏付け}

一般消費者が商品を選択する判断基準として, 「おいしいこと」「高すぎないこと」「安全安心であ ること」があげられますが, 安全・安心の違いは 以下のように考えています。

『安全』之は〜科学的根拠に基づいて作られた社会・ 公的なあの

『安心』之は〜心理的・感性的なもの（正直さ、リス ク対応力、理念など)

、『安全を遵守してくれている、いざというと きに即時に対応してくれる』という信頼を 寄せ弓れるか

*安全への期待

肥育 (飼料, 医薬品など), 加工, 流通過程での

安全基準が, 科学的に整備されることを望みます。 
2003，12月

特に, 農薬・動物用医薬品の食品への残留問題 については, 残留基準のないものは規制の対象に なっていなかったことは，消費者には知られてい ませんでした。このことは食の安全を求める運動 の中でも，かなり重要な項目でありましたが，実 現までにはハードルの高い課題に思えました。

しかし結局，この間の一連の事例から，厚生労 働省は 6 月に残留農薬に包括基準を作ることを発 表しました。3 年以内に制度移行し, 農薬や飼料, 動物用医薬品の残留基準を定めて，その基準を越 えた食品の製造や輸入，加工，販売などを禁止す る具体的な仕組みとなるようです。

生産流通する立場からは厳しい内容にもとれる かと思いますが, 基準がなく実態がわからないこと で消費者が漠然と抱いていた不安が解消されるこ と, また法整備の遅れと曖昧な農薬の管理のため に, 貴重な農作物を廃棄してきたようなことがなく なるのであれば, 大きな前進につながると思います。

\section{*安心のよりどころ}

基準が早急に整備された上で, 消費までの各段 階で法に基づいた運用がされたかチェック出来る 記録作りと，その管理の仕組みを望みます。

・定期点検により, 記録内容の確認がされること

・必要な時に, 記録を検索, 確認, 公開できる こと

・必要な履歴が, 生産から流通の各段階で原 料・製品に添付されていること

・消費者が購入する際に必要な表示がされてい ること

・表示にウソがないこと

マスコミではトレーサビリティーと, 店頭での 検索システムなどが取り上げられていますが，そ の為には, 必要な記録を正確に残すための, シン プルで簡単に誰であ使える記録システムが必要と 思います。

\section{4. コープ十勝での商品提供}

コープ十勝は, 創立 27 年, 16,000 人利用の協同 購入を中心に, 店舗が 1 つ, 総事業高は 68 億円の 小さな生協です。カタログでの協同購入が中心で したので, 地域の食材を生かした商品づくりを心
日豚会誌 40 巻 4 号

がけ, 生産者の方のとの交流, 組合員への情報提 供を大切にしてきました。

組合員の 2002 年度の年間豚肉利用金額は, 店 舗で 6300 万円, 協同購入で 5200 万円の実績で す。原料はすべて道内産のむのを供給していま す。中でも十勝管内 2 名の生産者の方とは定期的 に担当バイヤーと肥育管理に関する情報交換を し，また組合員との交流もできる，いわゆる産直 商品として『十勝野ポーク』の名称で提供してい ます。

また黒豚についても，管内の別の 2 名の生産者の 方から提供されており,『十勝育ち黒豚』の名称で 生産者の顔が見える商品として支持されています。

\section{5. 消費者が求める安全安心}

消費者が判断する手がかりは表示しかありませ んが, 店頭や商品ラベルでの情報は限界がありま す。では消費者は購入にあたってどんな情報がほ しいのか。

この間牛についてはトレーサビリティーの導入 が進められており, 大手スーパーや生協の中であ 店頭でパソコンでバーコード入力で履歴を確認で きることが話題になっていますが，果たして慨や 医薬品の名前を見てどれだけの人がわかるのか疑 問です。

意図的にウソをつくのであれば言語道断，どん なシステムを入れてむ, 安心の後ろ盾は崩れてし ますのですが，今後は正しく管理され，トレーサ ビリティー情報が正確に各段階に伝えられ, 必要 なときには即時に検索されるように整備されるの であれば，消費者は複雑な細かい情報まで商品に 記載されることは望んでいないと思います。

消費者が求める安心は,「法を遵守した安全な 管理がされ, 記録, 点検が行われ, 必要であれが 情報開示できる体制が整備されること」が実現で きれば, 購入時には産地, 品種, 部位, 加工日,

量目など必要な表示項目が「正しく」表示されて いることで, 十分ではないかと思います。

ただし，いまだに偽装表示が報道される現実を みると, 不信感は簡単には拭い去れないですの で,「正直である」というモラルの確立は大変重要 な事だと思います。 